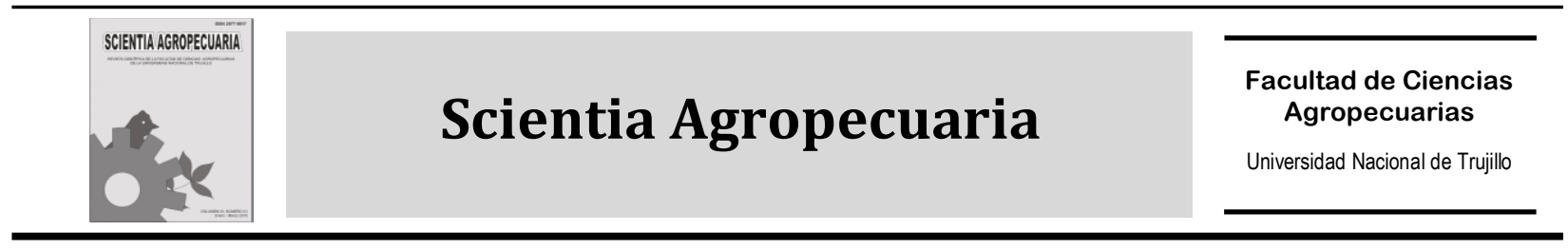

\title{
Separación de proteínas de suero de leche por cromatografía líquida
}

\section{Separation of whey proteins for chromatography liquid}

\author{
Abraham D. Giraldo Zuñiga ${ }^{a, *}$, Edwin E.García Rojas ${ }^{b}$, Jane S. R.Coimbra ${ }^{c}$, Wilmer E. \\ Luera Peña ${ }^{d}$ \\ ${ }^{a}$ Curso de Engenharia de Alimentos, Universidade Federal do Tocantins (UFT), 77020-210 - Palmas - TO, Brazil. \\ ${ }^{b}$ Departamento de Engenharia de Agronegócios, Universidade Federal Fluminense (UFF) Av. dos, Trabalhadores $N^{\circ} 420$, Zip \\ Code 27255-250, Volta Redonda, RJ, Brazil, \\ ${ }^{c}$ Departamento de Tecnologia de Alimentos, Universidade Federal de Viçosa (UFV), 36571-000 - Viçosa - MG, Brazil. \\ d Departamento de Engenharia Rural, Universidade Federal do Espírito Santo (UFES) Alto Universitário, s/n, Zip Code 29500- \\ 000, Alegre, ES, Brazil.
}

Recibido 20 Febrero 2010; aceptado 20 Marzo 2010

\begin{abstract}
Resumen
Este artículo describe y compara tres métodos cromatográficos para el análisis y la cuantificación de las proteínas más abundantes en el suero de queso, $\alpha$-lactoglobulina y $\beta$-lactoalbúmina. Los métodos fueron los siguientes: cromatografía líquida de alta eficacia en fase reversa, cromatografía de intercambio aniónico y cromatografía de exclusión molecular. La cromatografía líquida en fase reversa condujo a una mejor separación de las proteínas de suero de leche que la cromatografía de exclusión molecular y la cromatografía de intercambio aniónico, este método ofrece una excelente separación de las proteínas de suero de leche, y presentó un breve tiempo de análisis (33 min).
\end{abstract}

Palabras clave: RP-HPLC, cromatografía de intercambio aniónico, cromatografía de exclusión molecular, $\alpha$ lactoglobulina, $\beta$-lactoalbúmina.

\begin{abstract}
This paper describes and compares three chromatographic methods for the analysis and quantification of most abundant proteins in cheese whey, $\alpha$-lactalbumin and $\beta$-lactoglobulin. The methods were: Reverse-phase high performance liquid chromatography, anion Exchange chromatography and size-exclusion chromatography. The reverse- phase liquid chromatography led to a better separation of whey proteins than size-exclusion chromatography and anion exchange chromatography, this method offered an excellent separation for whey proteins and presented a short time of analysis (33 $\mathrm{min})$.
\end{abstract}

Key Words: RP-HPLC, anion-exchange chromatography, size-exclusion chromatography, $\alpha$-Lactalbumin, $\beta$ Lactoglobulin.

\section{Introduction}

Cheese whey is a dairy industry by-product, contains approximately $20 \%$ of the total milk protein and have the advantage of being a low cost source of protein (McIntosh et al., 1998) volume produced worldwide (2001) was approximately 91 million tons (FAO, Jan, 2004). High functional and nutritional

\footnotetext{
* Autor para correspondencia. Tel: 55-63-218-2923, Fax: 55-63- 218 - 2924.

E-mail: abraham@uft.edu.br (A. Giraldo-Zuñiga)
} 
properties are characteristics of whey proteins. One way of using these for human consumption is in food preparations (Wit, 1998; Mor and Há, 1993). The proteins present in most quantity in cheese whey are $\alpha$ lactalbumin $(\alpha-\mathrm{la})$ and $\beta$-lactoglobulin $(\beta-\lg )$, with concentrations of 1 to $1.5 \mathrm{~g} /$ litre and 2 to $4 \mathrm{~g} /$ litre, respectively. The high added value of cheese whey proteins and their wide applicability in the food and pharmaceutical industries justify the development of separation and purification processes of these proteins.

Several methods have been proposed as liquid-liquid extraction (Coimbra et al., 1994), chromatographic methods (Rojas et al., 2004; Gurgel et al., 2001; Gerberding and Byers, 1998), thermal isoelectric or chemical precipitation (Bramaud et al., 1995; Igarashi, 1995) and membrane filtration (Zydney, 1998). However, it is necessary to establish fast and analytical methods to determine these proteins. There is already an abundance of literature concerning whey protein analysis. Methods include gel electrophoresis, liquid chromatography, capillary electrophoresis and immunochemical detection (Strange et al., 1992; Jong et al., 1993; Kinghorn et al., 1995). By far the most used method for whey protein analysis is liquid chromatography.

In particular high-performance liquid chromatography (HPLC) has become one of the main techniques in the dairy con industry as it combines versatility; short analysis time and high resolution power (Elgar et al., 2000). There are a large number of methods described for ion-exchange, size-exclusion, hydrophobic interaction and reversed-phase.

In this work, describes three chromatographic methods for rapid qualitative and quantitative analysis of $\alpha$-la and $\beta$-lg in Mozzarella fresh whey produced in our dairy plant, using anion-exchange chromatography (AEC), sizeexclusion chromatography (SEC) and reverse phase high performance liquid chromatography (RP-HPLC).

\section{Materials and methods}

\subsection{Chemical and reagents}

$\alpha$-la and $\beta-\lg$ were purchased from Sigma Chemicals (St. Louis, USA) and whey in natura from FUNARBE dairy plant (Viçosa, Brazil). All other reagents were of analytical grade. Ultrapure water for all the experiments was obtained from a Milli-Q system (Millipore Inc., MA, USA).

\subsection{Chromatography Materials}

Superdex 75 HR 10/30 (30 x 1 cm I.D.) fractionation range (Mr 3000 - 70000) and Mono Q HR 5/5 (5x0.5 cm I.D.) columns were purchased from Pharmacia Biotech (Uppsala, Sweden). Shim-pack CLC-ODS (M)® $\mathrm{C} 18$ reversed-phase column $(250 \mathrm{~mm} \times$ $4.6 \mathrm{~mm}, 5$ _m particle diameter and $100 \AA$ pore diameter, Shimadzu, Tokyo, Japan) preceded by a guard column of the same material $(10 \mathrm{~mm} \times 3.2 \mathrm{~mm})$. Two chromatographs were used. SEC and AEC were performed with ÄKTA Purifier ${ }^{\circledR}$ system (Amersham Pharmacia Biotech, Uppsala, Sweden). The eluent was monitored by UV absorption UV900 at $280 \mathrm{~nm}$. RP-HPLC chromatography was performed using a Shimadzu HPLC system (LC-10VP, Japan) with a LC-10ADVP pump, a SIL-10ADVP autosampler (Shimadzu, Japan) and a SPD-M10AVP photodiode array detector (Shimadzu, Japan) set at $210 \mathrm{~nm}$. Data were analyzed using Class VP5.02 computer software (Shimadzu, Japan).

\subsection{Chromatography}

The anion-exchange Mono Q HR 5/5 column was equilibrated with $10 \mathrm{mM}$ potassium phosphate buffer (pH 7.0) using the ÄKTA purifier® system. A $1 \mathrm{~mL}$ volume of standard and whey in nature was injected into the column, room temperature. Elution was conducted by increasing $\mathrm{NaCl}$ concentration in the same buffer as shown in Table 1. Superdex 75 HR 10/30 column was equilibrated with $50 \mathrm{mM}$ potassium phosphate 
buffer ( $\mathrm{pH} 7.0$ ) containing $0.15 \mathrm{M} \mathrm{NaCl}$, using the ÄKTA Purifier ${ }^{\circledR}$ system at room temperature. A $100 \mu \mathrm{L}$ sample of the standard and whey in nature were applied to the column.

\section{Table 1}

Parameters for the elution of whey proteins from the anion-exchange Mono Q HR 5/5 column.

\begin{tabular}{ccc}
\hline Time $(\min )$ & $\mathrm{A}(\%)$ & $\mathrm{B}(\%)$ \\
\hline $0-20$ & 90 & 10 \\
$20-25$ & 90 & 10 \\
$25-40$ & 70 & 30 \\
$40-50$ & 0 & 100 \\
\hline
\end{tabular}

A, B: $10 \mathrm{mM}$ potassium phosphate buffer B: containing $1.0 \mathrm{M} \mathrm{NaCl}$.

Proteins were eluted with the same buffer at a flow-rate of $1.0 \mathrm{~mL} / \mathrm{min}$. For RP-HPLC, the column was equilibrated with $0.15 \mathrm{M} \mathrm{NaCl}$ (Merck, Germany) and $\mathrm{pH}$ 2.5. Temperature of $40{ }^{\circ} \mathrm{C}$, sample injection volume of $20 \mu \mathrm{L}$ volume and mobile phase flow rate of 1 $\mathrm{mL} / \mathrm{min}$. Mobile phase A was constituted by $\mathrm{NaCl} 0.15 \mathrm{M}, \mathrm{pH} 2.5$ and mobile phase B by acetonitrile (Merck, Germany). The gradient program employed is shown in Table 2.

\section{Table 2}

Parameters for the elution of whey proteins from the RP-HPLC, the CLC ODS-C18 column.

\begin{tabular}{ccc}
\hline Time $(\min )$ & $\mathrm{A}(\%)$ & $\mathrm{B}(\%)$ \\
\hline $0-3$ & 64 & 36 \\
$3-27$ & 52 & 48 \\
$27-30$ & 100 & 0 \\
\hline
\end{tabular}

A: $0.15 \mathrm{M} \mathrm{NaCl}, \mathrm{pH} 2.5$

B: Acetonitrile $100 \%$

For the three chromatography techniques were obtained $\alpha$-la and $\beta$-lg standard curves using solutions of pure proteins in concentrations ranging from $0.02 \mathrm{mg} . \mathrm{mL}-1$ to $2.0 \mathrm{mg} \cdot \mathrm{mL}^{-1}$ and the samples filtered in cellulose acetate membrane of $0.22 \mu \mathrm{m}$ (Durapor, Brazil).

\section{Results and discussion}

The analyses were conducted in triplicate and the determination coefficient for each standard curve calculated by linear regression analysis (Table 3) and quantitative analysis of $\alpha$-la and $\beta$-lg in Mozzarella fresh whey (Table 4).

Table 3

Coefficients of equation* for each standard curve.

\begin{tabular}{lccc}
\hline \multicolumn{1}{c}{ Method-protein } & $a$ & $b$ & $R^{2}$ \\
\hline AEC-alfa & 1703.1 & 32.285 & 0.985 \\
AEC-beta & 1397.9 & 270.57 & 0.989 \\
RP-HPLC-alfa & $2 \mathrm{E}+07$ & 853496 & 0.997 \\
RP-HPLC-beta & $2 \mathrm{E}+07$ & $2 \mathrm{E}+06$ & 0.997 \\
SEC-alfa & 133.7 & 12,26 & 0.956 \\
SEC-beta & 68.43 & 7.85 & 0.990 \\
\hline
\end{tabular}

$* y=a x+b$

Table 4

Quantitative analysis of $\alpha-\mathrm{la}$ and $\beta-\lg$ in Mozzarella fresh whey.

\begin{tabular}{ccc}
\hline Method-protein & $\alpha$-la $(\mathrm{g} / \mathrm{L})$ & $\beta-\lg (\mathrm{g} / \mathrm{L})$ \\
\hline AEC & $1.25 \pm 0.027$ & $3.15 \pm 0.028$ \\
RP-HPLC & $1.32 \pm 0.021$ & $3.32 \pm 0.018$ \\
SEC & $1.68 \pm 0.031$ & $3.75 \pm 0.035$ \\
\hline
\end{tabular}

\subsection{Anion-exchange chromatography}

The Figure 1 standard proteins $\alpha$-la was eluted in peak 1 and $\beta$-lg in peak 2 . Whey in natures (Figure 2) $\alpha$-la and $\beta$-lg were eluted in the peak 3 and 4 , respectively.

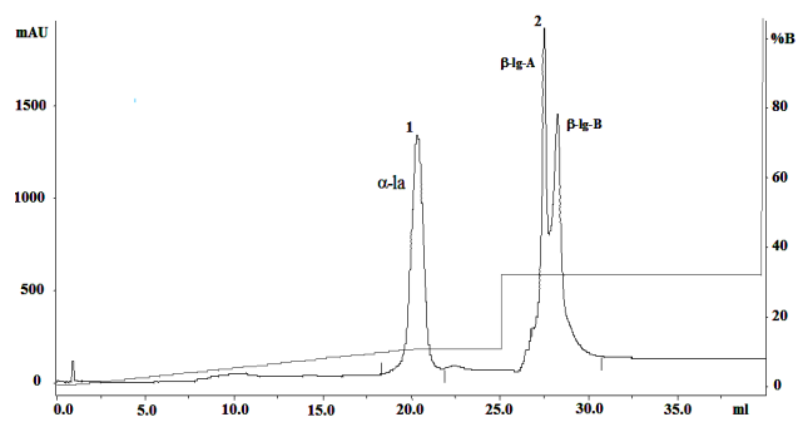

Figure 1. Typical chromatogram of standards $\alpha$-la and $\beta-\lg$ for the AEC.

The complete elution was achieved within 50 min. This technique presented a good resolution in the separation of the proteins as observed in the times of retention for each 
protein 20 and $27 \mathrm{~min}$ for $\alpha$-la and $\beta$-lg respectively. As well was effective for peak separation for the $\beta-\lg A$ and $\beta-\lg B$. In the ion-exchange chromatography the interaction between a protein and ion exchange depends the surface charge distribution, $\mathrm{pH}$, and the nature of particular ions in the solvent, such as properties of the ion exchange (Janson and Rydén, 1998).

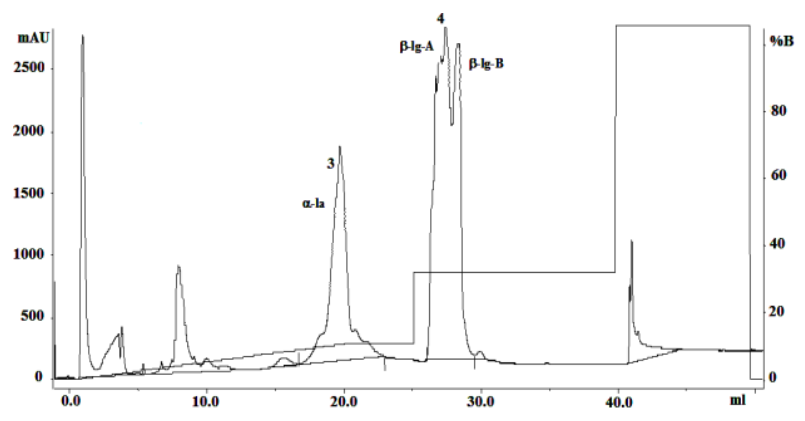

Figure 2. Chromatogram of Mozzarella fresh whey for the AEC.

The $\mathrm{pH}$ (7.0) employee in this work, was superior to the point isoelectric of the proteins studded, favored the surface negative of the proteins, as well as the increment of the concentration of $\mathrm{NaCl}$ in the phase mobile produced the elution of the proteins retained in the column. According to its isoelectric point we assumed that serum albumin was eluted in peak 1 .

Similar results were reported by others authors (Andrews et al., 1985) in the analyses of whey proteins by AEC employed a Mono Q column.

\subsection{Size-exclusion chromatography (SEC)}

Figures 3 and 4 shows chromatographic profiles of standard proteins and Mozzarella fresh whey, respectively. The complete elution was achieved within approximately $30 \mathrm{~min}$. The $\beta$-lg was eluted before the $\alpha$-la due to the difference in the molecular masses of $\beta-\mathrm{lg}$ (18000 Da) and $\alpha$-la (14500 Da). In the SEC, proteins injected into the column are separated according to decreasing size due to incompatibility between the solute dimensions and the pore size of the support (Janson and Rydén, 1998).

This technique was not effective for peak separation of $\beta-\lg A$ and $\beta-\lg B$ showing like this a low resolution in the separation of the studied proteins, similar values were reported for other authors that used the following sizeexclusion columns to separation of bovine whey protein: a RP 318 column (GonzalezLlano et al., 1990) and a Superose 12 column (Andrews et al., 1985). However, Harrison (1994) concluded that the SEC is a relatively low-resolution analytical technique but provides the advantages of accurate quantification, insensitivity to charge, and can be used with detergents.

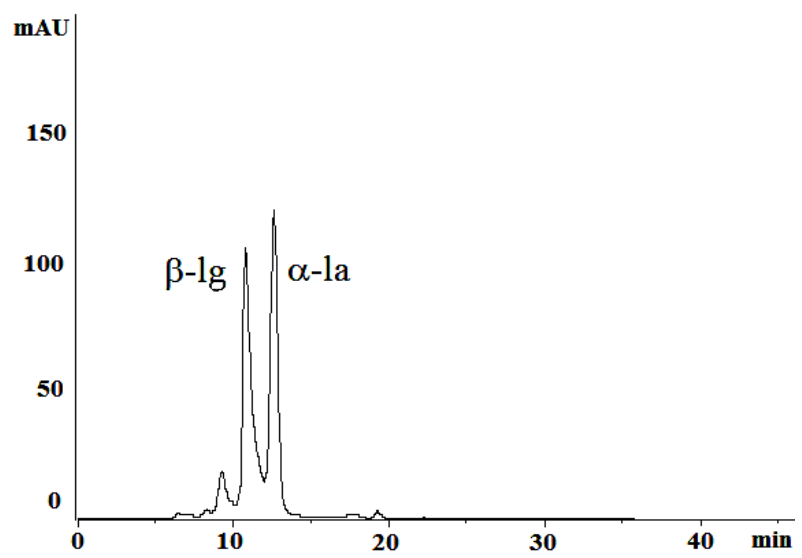

Figure 3. Typical Chromatogram of standards $\alpha-$ la and $\beta-\lg$ for the SEC.

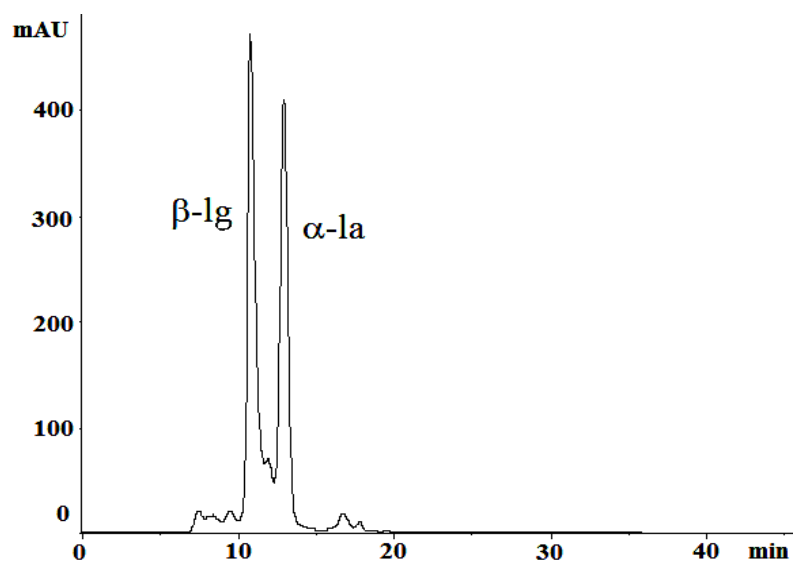

Figure 4. Chromatogram of Mozzarella fresh whey for the SEC. 


\subsection{Reversed-phase Chromatography (RP- HPLC)}

In Figure 5, it is shown a chromatogram of the pure proteins samples used to build the calibration curves, in which two peaks for $\beta$-lg were obtained.

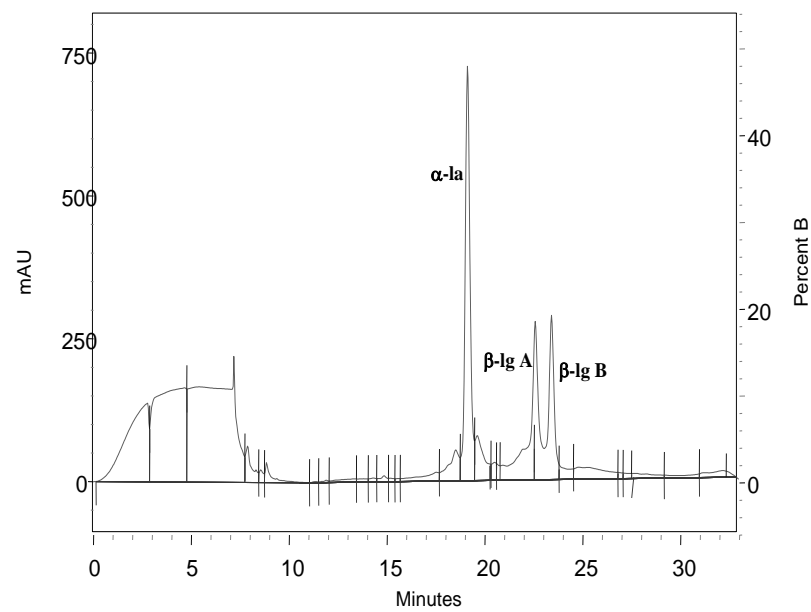

Figure 5. Typical Chromatogram of standards $\alpha$ la and $\beta$-lg for the RP-HPLC.

Was due to the fact that $\beta-\lg$ is a dimer formed by $\beta-\lg \mathrm{A}$ and $\beta-\lg \mathrm{B}$ (Cayot and Lorient, 1997). The chromatography conditions used were found to allow good resolution, in a short time of analysis ( $33 \mathrm{~min}$ ), to separate $\beta-\lg \mathrm{A}$ and $\beta-\lg \quad$ B. The technique was also appropriate for quantification of Mozzarella fresh whey (Figure 6). RP-HPLC is a chromatographic technique that is primarily sensitive to differences in hydrophobicity and has been widely applied to the analysis of proteins and peptides (Harrison, 1994).

Low ionic strengths can be used at low pHs, facilitating easier recovery, better peak shape, and more reproducibly retention (Janson and Rydén, 1998). Recently was developed a perfusion RP-HPLC method to simultaneously separate soybean, bovine and caprine whey proteins, the authors (Ferreira and Cacote, 2003; Elgar et al., 2000; Garcia et al., 1998) obtained the optimal conditions for the separation using a binary gradient wateracetonitrile-trifluoroacetic acid and a reversed-phase column that contains a polystyrene-divinylbenzene copolymer-based packing. In this work of low $\mathrm{pH}$ employed (2.5) and ionic force $(0.15 \mathrm{M} \mathrm{NaCl})$ used in the gradient by the elution of $\alpha-\mathrm{la}$ and $\beta-\mathrm{lg}$ produced an optimal resolution in the separation of these proteins. For the three techniques chromatography described in this work, there was intermediate precision of the times of retention of the peaks chromatography, the technique of RP-HPLC showed better results concerning repeatability, with a variation of approximately $\pm 2 \%$.

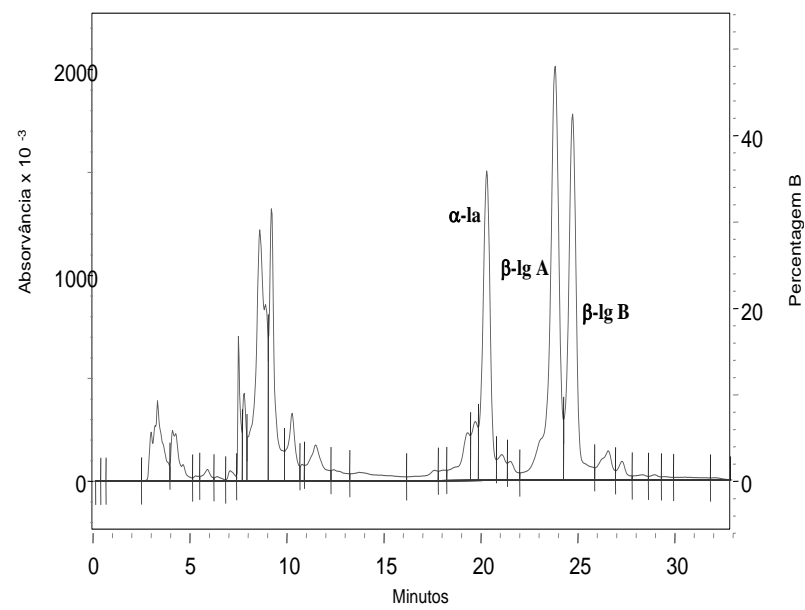

Figure 6. Chromatogram of Mozzarella fresh whey for the RP-HPLC.

In the quantification of the proteins $\alpha-\operatorname{la}$ e $\beta-\lg$ presented in Mozzarella fresh whey can be observed that the technique of SEC presented smaller values of the proteins and the variation of the times of retention of the picks they were of approximately $3.5 \%$.

\section{Conclusions}

The proteins $\alpha$-la and $\beta$-lg were satisfactorily separated and quantified by the application of three different chromatography methods. The technique of RP-HPLC showed better results with a precision of $\pm 2 \%$, presenting a high efficiency in the peak separation as well as a relatively short time of analysis (33 min). 


\section{Acknowledgement}

\section{The authors are grateful to FAPEMIG, CNPq and FAPERJ for the financial support.}

\section{References}

Andrews, A.T.; Taylor, M.D.; Owen, A.J. 1985. Rapid Analysis Of Bovine Milk Proteins By Fast Protein Liquid Chromatography. Journal of Chromatography A 348: 177185.

Bramaud, C.; Aimar, P.; Daufin, G. 1995. Thermal isoelectric precipitation of $\alpha$-lactalbumin from a whey protein concentrate: influence of protein-calcium complexation. Biotechnol. Bioeng. 47: 121-130.

Cayot, P.; Lorient, D. 1997. Structure-Function relationships of Whey proteins, in: Food Proteins and Their Applications, New York: Marcel Dekker.

Coimbra, J.R.; Thömmes, J.; M.R.; Kula. 1994. Continuous separation of whey proteins with aqueous two-phase system in a Graesser contactor. Journal Of Chromatography A 668: 85-94.

Elgar, D.F.; Norris, C.S.; Ayers, J.S.; Pritchard, M.; Otter, D.E.; Palmano, K.P. 2000. Simultaneous separation and quantitation of the major bovine whey proteins including proteose peptone and caseinomacropeptide by reverse phase high performance liquid chromatography on polystyrene-divinylbenzene. Journal Of Chromatography A 878: 183-196.

Ferreira, I.M.P.L.V.O.; Caçote, H. 2003. Detection and quantification of bovine, ovine and caprine milk percentages in protected denomination of origin cheeses by reversed-phase high-performance liquid chromatography of beta-lactoglobulins. Journal of Chromatography A 1015: 111-118.

Food and Agriculture Organization of the United Nations 2004. http://www.fao.org (Jan, 2004).

Garcia, M.C.; Marina, M.L.; Torre, M. 1998. Ultrarapid detection of bovine whey proteins in powdered soybean milk by perfusion reversed-phase high-performance liquid chromatography. Journal of chromatography A 822: 225232.

Geberding, S.J.; Beyers, C.H. 1998. Preparative ionexchange chromatography of proteins from dairy whey. Journal Of Chromatography A 808: 141-151.
Gonzalez-Llano, D.; Polo, C.; Ramos, M. 1990. Update on HPLC and FPLC analysis of nitrogen compounds in dairy products. Lait. 70: 255-277.

Gurgel, P.V.; Carbonell, R.G.; Swaisgood, H.E. 2001. Fractionation of whey proteins with a hexapeptide ligand affinity resin. Bioseparation 9: 385-392.

Harrison, R.G. 1994. Protein purification process engineering. New York: Marcel Dekker.

Igarashi, Y. 1995. An improved procedure for the preliminary fractionation of milk proteins. International Dairy Journal 5: 305-310.

Janson, J.C.; Rydén, L. 1998. Protein Purification: principles, high resolution methods and applications. New York: John Wiley \& Sons.

Jong, N.; Visser, S.; Olieman, C. 1993. Determination of milk proteins by capillary electrophoresis. Journal Of Chromatography A 652: 207-213.

Kinghorn, N.M.; Norris, C.S.; Paterson, G.R.; Otter, D.E. 1995. Comparison of capillary electrophoresis with traditional methods to analyse bovine whey proteins. Journal Of Chromatography A 700: 111-123.

McIntosh, H.G.; Royle, P.J.; Richard, K.LL.; Geoffrey, R.; Johnson, M.; Grinsted, R.L. 1998. Whey proteins as functional food ingredients? Int Dairy Journal 8: 425-434.

Moor, C.; Ha, E.W. 1993. Whey protein concentrates and isolates: processing and functional properties. Critical Reviews in Food Science and Nutrition 33(6): 431-476.

Rojas, E.E.G.; Coimbra, J. R., Minim, L. A., Zuniga, A. D. G., Saraiva, S. H., Minim, V.P.R. 2004. Size-exclusion chromatography applied to the purification of whey proteins from the polymeric and saline phases of aqueous two-phase systems. Process Biochemistry 39: 1751-1759.

Strange, D.E., Malin E.L., Hekken D.L.V., Basch J. J. 1992. Chromatographic and electrophoretic methods used for analysis of milk proteins. Journal Of Chromatography A 624: 81-102.

Wit, J.N. 1998. Nutritional and functional characteristics of whey proteins in food products. Journal Dairy Science 81:597-608.

Zydney, A.L. 1998. Protein separations using membrane filtration: new opportunities for whey fractionation. International Dairy Journal 8: 243- 250. 